\title{
Morphometrics and Length-weight Relationship of Charybdis natator from Gulf of Mannar, India
}

\author{
V. Vidhya ${ }^{1}$, P.Jawahar ${ }^{1 *}$ and K. Karuppasamy ${ }^{2}$ \\ ${ }^{1}$ Department of Fisheries Biology and Resources Management, Fisheries College and \\ Research Institute, Thoothukudi 628008, India \\ ${ }^{2}$ ICAR-CMFRI, Tuticorin Research Centre, Tuticorin -628 001, India \\ *Corresponding author
}

\section{A B S T R A C T}

\section{Keywords}

Charybdisnatator, Morphometric,

Characters,

Relationship,

Positive correlation,

Gulf of Mannar

Article Info

Accepted:

07 November 2018

Available Online:

10 December 2018
The length - weight relationship of Charybdis natator (Herbst, 1794) was studied from Gulf of Mannar for a period of one year. The interrelationship between carapace width, carapace length, chelarpropodus length, weight and abdominal width in males as well as females, were estimated. Fishing activities are carried out throughout the year. The carapace width of the crabs ranged from $2.4 \mathrm{~cm}$ to $12.8 \mathrm{~cm}$, carapace length ranged from $1.9 \mathrm{~cm}$ to $9.5 \mathrm{~cm}$ and the weight ranged from 20 to $659 \mathrm{~g}$. The smaller sized male and female C.natator species were recorded during October and February respectively. The coefficient of correlation (r) obtained for the carapace length-weight (Male - 0.910; Female - 0.837; Pooled data- 0.902) and carapace width -weight of males, females and pooled data were nearly equal to $1(0.928,0.913$ and 0.934 respectively) indicating that the values were significant and hence, high degree of positive correlation existed between width weight and length-weight in these crabs. Analysis of covariance of carapace width - weight data in the species between the regression equations in males and females were highly significant. The present results indicated that males are heavier than females at any given length / width in this species.

\section{Introduction}

Crustaceans are a diverse group of arthropods and many crustaceans are of great direct and indirect important to humans because of their large role in marine food chains. Crabs are one of the commercially important crustacean groups. A total of 990 species of marine brachyuran crabs belonging to 281 genera and 36 families were reported from Indian waters (Kathirvel, 2008). In India, the fishery of edible crabs is sustained mainly by crabs of the family Portunidae. They are caught as a bycatch in trawling as well as main catch by the specialized bottom set gill nets, locally known as 'nanduvalai' in the Gulf of Mannar. There are 238 brachyuran crab species so far recorded in the coral reef areas of Gulf of Mannar. In Gulf of Mannar region C.natator was recorded throughout the year with peak during the month of in October and May for male and September for females. C.natator 
occurs from the intertidal zone (especially juveniles) to depths of $15-35 \mathrm{~m}$. It inhabits sandy / pebbles/rocky bottom, and also in brackish water subtropical and tropical climates. The portunid crab $C$. natator exists in the commercial catches of the Gulf of Mannar. Although edible worldwide, this crab is hardly known among local consumers. The interrelationships between various morphometric characters, viz., carapace width/length and chelar propodus length in males and carapace width/length and abdominal width/length in females were analyzed and presented. The results will be useful in comparing the different stocks of the same species at different geographical locations. Hence, it will be pertinent to describe the fishery of this important resource and also to study the growth and stock characters of the portunid crabs off Gulf of Mannar coast.

\section{Materials and Methods}

\section{Study area}

The present study was carried out for a period of 12 months from June 2015 to June 2016 from part of the Marine biosphere of Gulf of Mannar $\left(8^{\circ} 35^{\prime} \mathrm{N}-9^{\circ} 25^{\prime} \mathrm{N}\right.$ latitude and $78^{\circ} 08^{\prime} \mathrm{E}-79^{\circ} 30^{\prime} \mathrm{E}$ longitude), South East coast of India.

\section{Sample collection}

Charybdis natator samples were collected from four landing centers at Gulf of Mannar coast. The sample stations are Therespuram, Vellapatti, Vedalai and Periyapattinam. Fortnightly samples were taken from these landing centers (Fig. 1). The crabs were collected up to 10 to $15 \mathrm{~nm}$ from the sea shore in Gulf of Mannar region. From these stations sample of $C$. natator (Fig. 2) were collected and each crab was measured and recorded for its sex, carapace width, carapace length, abdomen width, chelate length and body weight by using Vernier calipers with an accuracy of $0.5 \mathrm{~mm}$. Carapace width (CW) was taken as the distance between the tips of the posterior most lateral carapace spines. Carapace length (CL) was measured dorsally along the midline, between the frontal notch and the posterior margin of the carapace. Right chelar propodus length $(\mathrm{Ch} \mathrm{L})$ was measured from the tip of the propodus fixed finger to the base of the propodus. The craft employed along the Gulf of Mannar coast includes trawlers, vallam, and small boats (vathai). Main gears employed in the crab fishery are crab traps, bottom set gill net, and trawl nets etc. A total of $786 C$. natator were collected for this study and of these 547male and 239 female of $C$. natator.

A scatter diagram each for males and females in respect of C.natator was obtained by plotting the weight against width and weight against length of individual crabs. From the closeness of the scatter and from the parabolic nature of plot, it is inferred that there exist a good relationship between width and weight, and between length and weight, as also the suitability of fitting the exponential formula, $\mathrm{W}=\mathrm{a} \mathrm{L}^{\mathrm{b}}$ to the data. The data of all specimens were pooled and the relationships between the different set of variables was calculated on the basis of individual measurements. The ' $t$ ' test was used to find out the significant differences if any, between Carapace width- weight relationship of male and female.

\section{Results and Discussion}

\section{Size composition}

Totally 786 individuals of $C$. natator were collected for the present study of which males constituted $69.59 \% \quad(\mathrm{n}=547)$ and females $30.4 \% \quad(n=239)$ respectively. The stock is composed of larger sized males compared to females and dominated by small female individuals in number. The carapace width ranged from $2.4 \mathrm{~cm}$ to $12.8 \mathrm{~cm}$, carapace 
length ranged from $1.9 \mathrm{~cm}$ to $9.5 \mathrm{~cm}$ and the weight ranged from 20 to $659 \mathrm{~g}$. The smaller sized male and female C.natator species were recorded during October and February (Fig. 5, 6 and 7). The size range of the crab C. natator in the gill net fishery of the Gulf of Mannar varying between 2.4 to $12.8 \mathrm{~cm}$ Carapace width $(\mathrm{CW})$ for males and from 5.1 to $11.8 \mathrm{~cm}$ for female, the carapace length ranged from $2.3 \mathrm{~cm}$ to $9.5 \mathrm{~cm}$ for male and for female it ranged from $1.9 \mathrm{~cm}$ to $8.6 \mathrm{~cm}$ and the weight ranged from 20 to $659 \mathrm{~g}$ for male and 28-268 for female was recorded during the present study.

\section{Length / width - weight relationship}

The scatter diagram for males and females was obtained by plotting weight against carapace width/length of individual crabs. From the data, a distinct relationship was found between width and total weight. The morphometric relationship was estimated for carapace length, width, chelate length-weight relationships and carapace length-width, carapace length-chelate length, carapace length, width - abdomen width relationships for male, female and pooled data of $C$. natator (Fig. 3 and 4).

\section{Carapace length/ width - body weight relationship}

The carapace length (CL) of $C$. natator was plotted against the weight (Wt) to estimate the CL-Wt relationship. CL varied from $2.3 \mathrm{~cm}$ to $9.9 \mathrm{~cm}$ for males and from 1.9 to $8.6 \mathrm{~cm}$ for females in $C$. natator while the $\mathrm{Wt}$ varied from 20 to $659 \mathrm{~g}$ for males and from 28 to 268 $\mathrm{g}$ for females. The carapace width of $C$. natator was plotted against the weight to estimate the $\mathrm{CW}-\mathrm{Wt}$ relationship. In $C$. natator the (carapace width) $\mathrm{CW}$ varied from 2.4 to $12.8 \mathrm{~cm}$ for males and from 5.1 to 11.8 $\mathrm{cm}$ for females. The coefficient of correlation (r) obtained for the carapace length -weight (Male - 0.910; Female - 0.837; Pooled data-
0.902) and carapace width -weight of males, females and pooled data were nearly equal to $1 \quad(0.928,0.913$ and 0.934 respectively) indicating that the values were significant and hence, high degree of positive correlation existed between width- weight and lengthweight in these crabs. The ' $b$ ' values of male (3.387) and female (2.958) of C.natator were analyzed against ' 3 ' with 100 degrees of freedom and which indicates that the ' $b$ ' value were highly significant at $1 \%$ and $5 \%$ level (Table 1).

\section{Carapace length - Carapace width $(\mathrm{CW})$ relationship}

The carapace length and width had a linear relationship with the following equations.

Male

$$
: \mathrm{CW}=0.030+1.449 \mathrm{CL}\left(\mathrm{R}^{2}=\right.
$$

$0.925)$

Female $\quad: \mathrm{CW}=0.078+1.437 \mathrm{CL}\left(\mathrm{R}^{2}=\right.$ 0.936)

Pooled data $: \mathrm{CW}=-0.005+1.454 \mathrm{CL}\left(\mathrm{R}^{2}=\right.$ 0.934)

Carapace length - Chelate length relationship

The relationship with carapace length (CL) and chelate length were estimated as below. The $\mathrm{R}^{2}$ values of male, female and combined of $C$. natator were $0.617,0.708$ and 0.614 for respectively.

Male $: \mathrm{CL}=-2.464+1.556 \mathrm{CL}\left(\mathrm{R}^{2}=0.617\right)$

Female $: \mathrm{CL}=-0.771+1.145 \mathrm{CL}\left(\mathrm{R}^{2}=0.708\right)$ Pooled data: $\mathrm{CL}=-2.643+1.557 \mathrm{CL}\left(\mathrm{R}^{2}=\right.$ $0.614)$

\section{Carapace length - Abdomen width (AW) relationship}

The allometric growth equations relating to carapce length - abdomen width relationship for male, female and pooled data of $C$. natator were given below. The $\mathrm{R}^{2}$ values of male, female and combined of $C$. natator were 
$0.42, \quad 0.167$ and 0.178 for respectively indicating a weak positive correlation.

Male: $\mathrm{AW}=1.304+0.294 \mathrm{CL}\left(\mathrm{R}^{2}=0.420\right)$

Female: $\mathrm{AW}=1.800+0.301 \mathrm{CL}\left(\mathrm{R}^{2}=\right.$ $0.167)$

Pooled data: $\mathrm{AW}=1.997+0.206 \mathrm{CL}\left(\mathrm{R}^{2}=\right.$ $0.178)$

\section{Carapace width - abdomen width relationship}

The allometric growth equations relating to
Carapace width - abdomen width relationship for male, female and combined of $C$. natator were presented in Figure 3. The $\mathrm{R}^{2}$ values of male, female and pooled data of $C$. natator were $0.398,0.141$ and 0.161 respectively.

Male: $\mathrm{AW}=1.446+0.187 \mathrm{CW}\left(\mathrm{R}^{2}=0.398\right)$

Female: $\mathrm{AW}=1.917+0.195 \mathrm{CW}\left(\mathrm{R}^{2}=\right.$ 0.141 )

Pooled data: $\mathrm{AW}=2.132+0.127 \mathrm{CW}\left(\mathrm{R}^{2}=\right.$ $0.161)$.

Table.1 Carapace width /length -total weight relationship in males and females of Charybdis natator

\begin{tabular}{|c|c|c|c|}
\hline \multirow[t]{3}{*}{ Male } & Carapace width -Total weight & $\begin{array}{l}\mathrm{W}= \\
0.104 \mathrm{~L}^{3.387}\end{array}$ & Allometric (+) \\
\hline & Carapace length -Total weight & $\mathrm{W}=0.346 \mathrm{~L}^{3.428}$ & Allometric (-) \\
\hline & Chelate length - Total weight & $\mathrm{W}=6.437 \mathrm{~L}^{1.703}$ & Allometric (-) \\
\hline \multirow[t]{3}{*}{ Female } & Carapace width -Total weight & $\mathrm{W}=0.245 \mathrm{~L}^{2.958}$ & Isometric \\
\hline & Carapace length -Total weight & $\mathrm{W}=0.758 \mathrm{~L}^{2.939}$ & Isometric \\
\hline & Chelate length - Total weight & $\mathrm{W}=11.88 \mathrm{~L}^{1.306}$ & Allometric (-) \\
\hline \multirow[t]{3}{*}{ Combined } & Carapace width -Total weight & $\mathrm{W}=0.110 \mathrm{~L}^{3.356}$ & Allometric (+) \\
\hline & Carapace length - Total weight & $\mathrm{W}=0.365 \mathrm{~L}^{3.388}$ & Allometric (+) \\
\hline & Chelate length - Total weight & $\mathrm{W}=6.221 \mathrm{~L}^{1.713}$ & Allometric (-) \\
\hline
\end{tabular}

Table.2 Length-weight relationship of Charybdis natator (Test of significance)

\begin{tabular}{|c|c|c|c|c|c|}
\hline Sex & Standard Error (S.E) & Slope (b)-3 & $\mathrm{t}=(\mathbf{b}-3 / \mathrm{S} . \mathrm{E})$ & \multicolumn{2}{|c|}{ Table ' $\mathrm{t}$ ' value } \\
\hline & & & $\mathbf{1 \%}$ & $\mathbf{5 \%}$ \\
\hline Male & 0.5187 & 0.387 & 0.1317 & \\
\hline Female & 0.3274 & 0.042 & 0.1282 & \\
\hline
\end{tabular}


Fig.1 Sampling stations at Gulf of Mannar (not to scale)

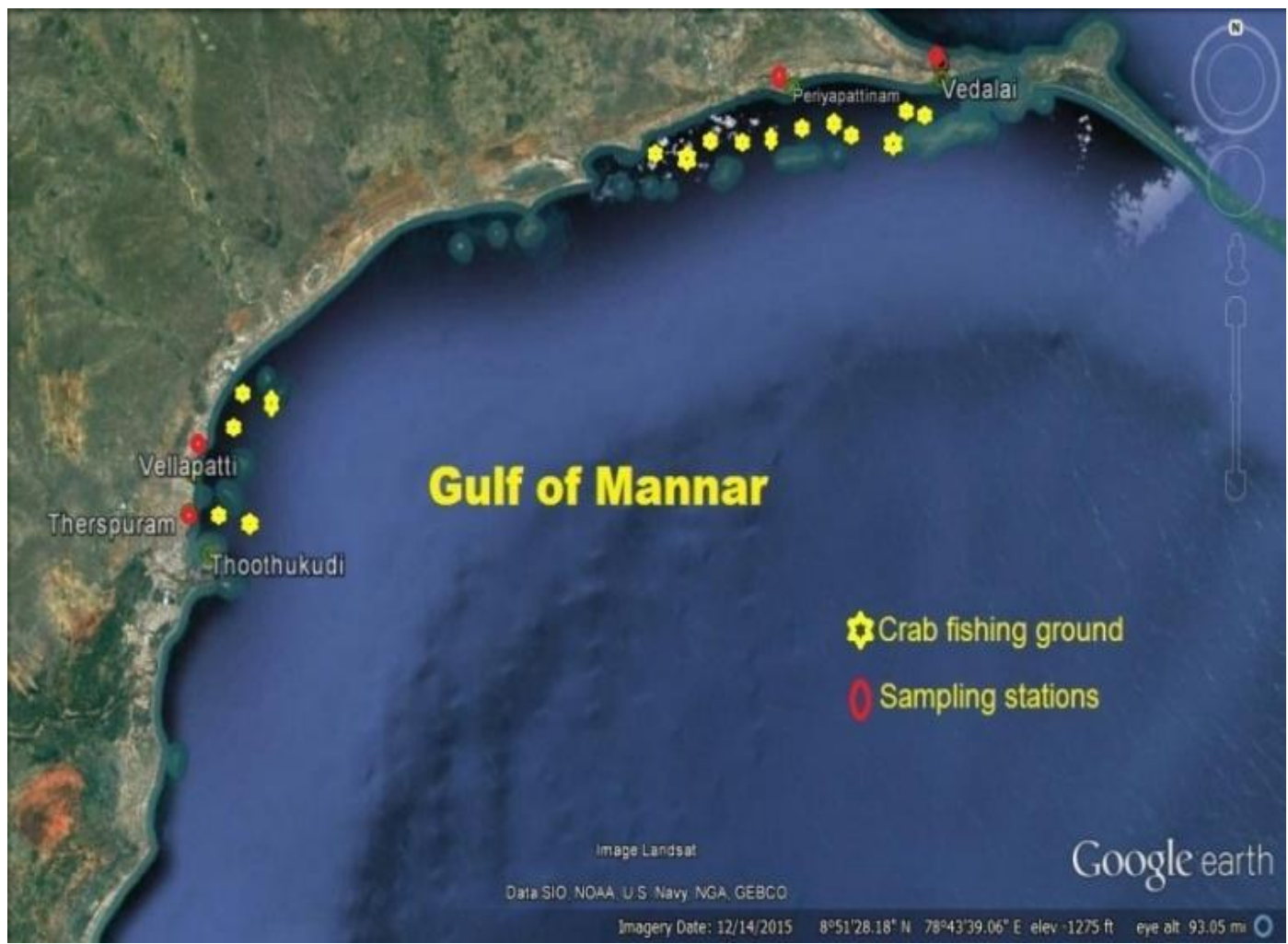

Fig.2 Charybdis natator

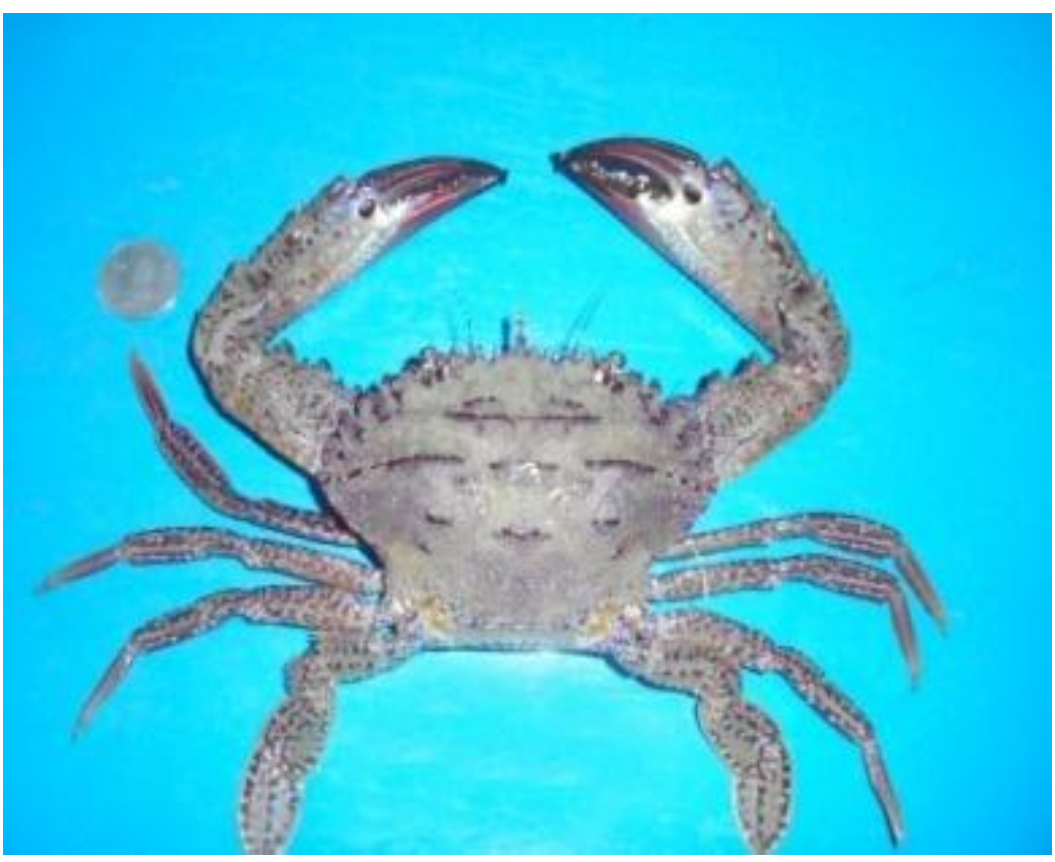


Fig.3 Morphomertric relationship of Charybdis natator

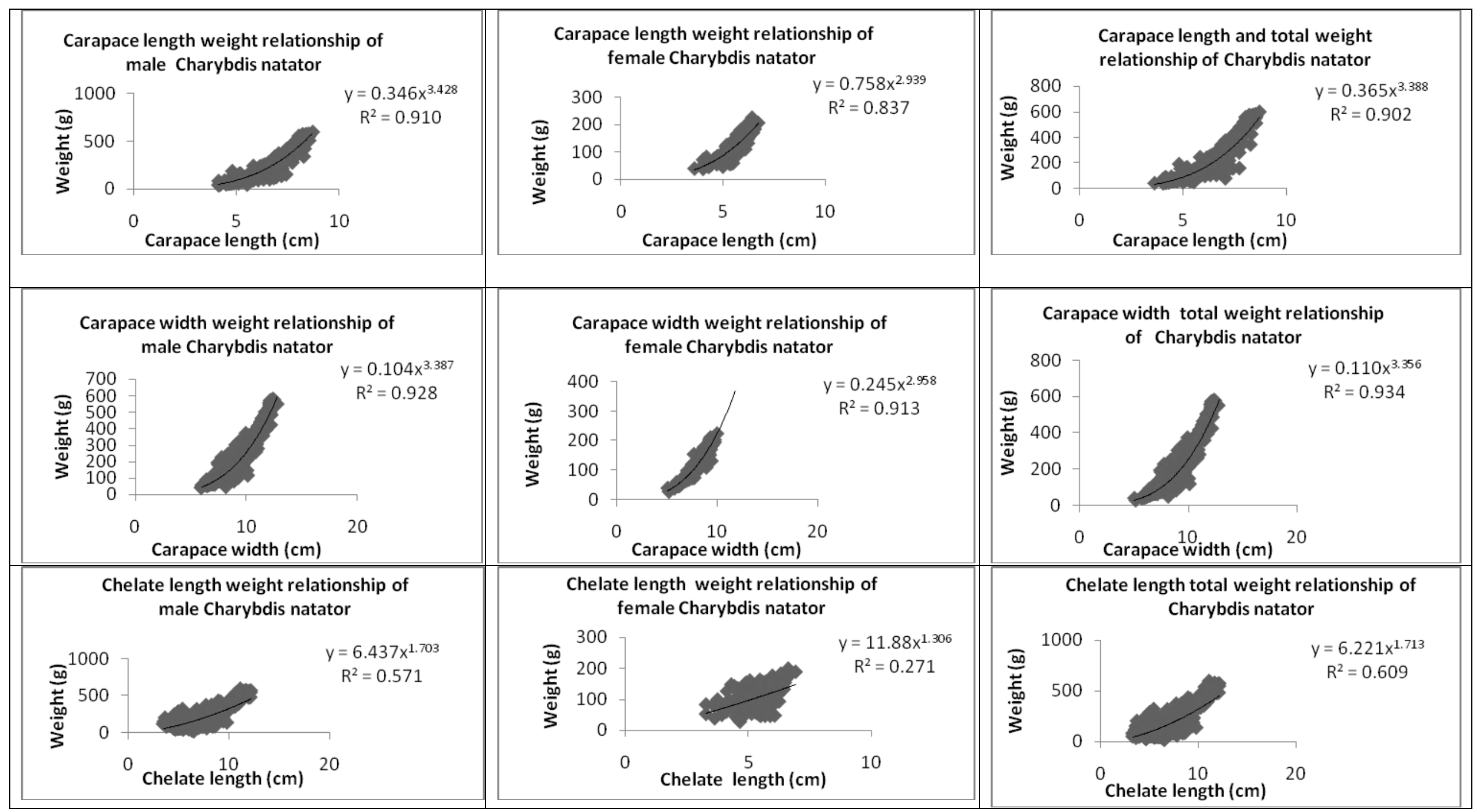


Fig.4 Morphomertric relationship of Charybdis natator

\begin{tabular}{|c|c|c|}
\hline 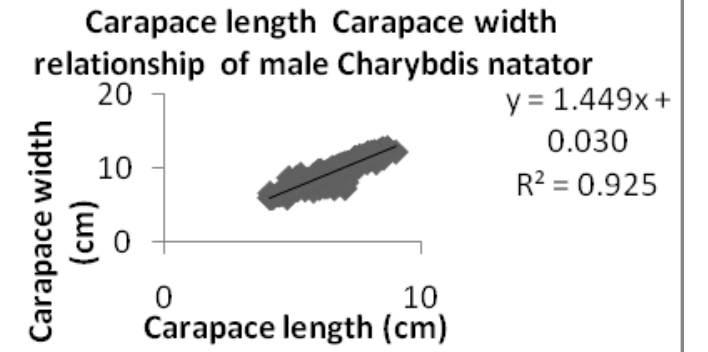 & 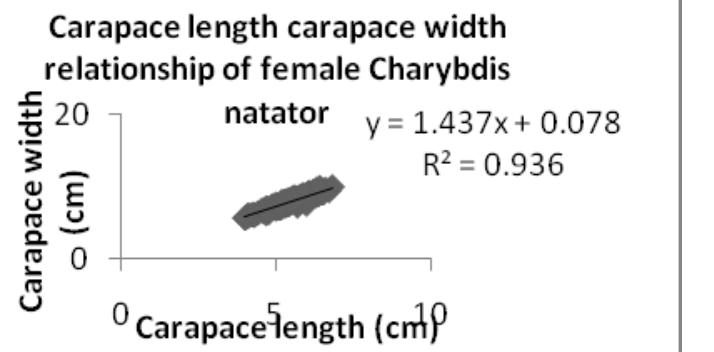 & 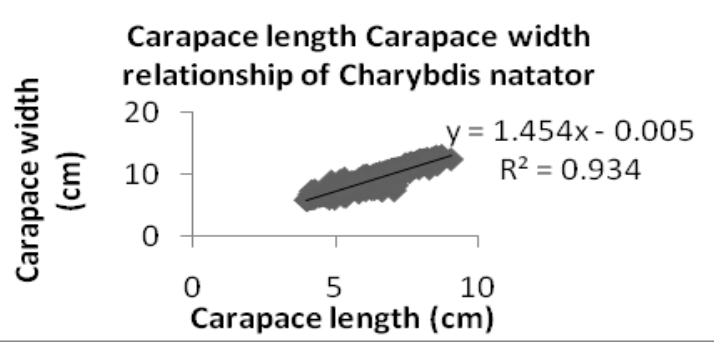 \\
\hline 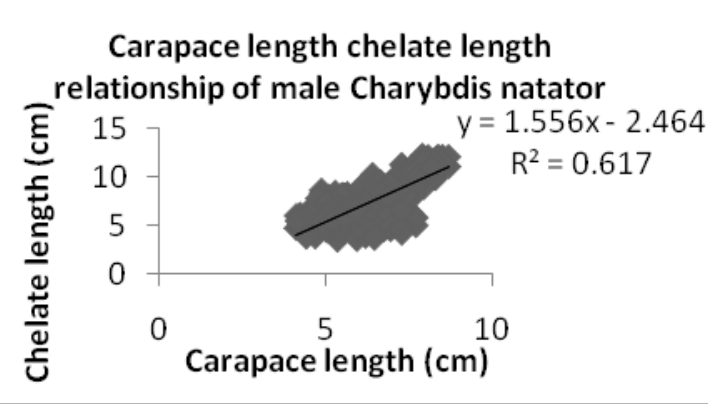 & 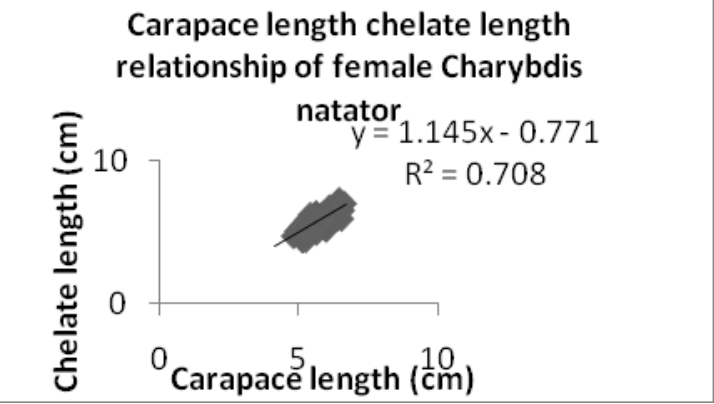 & 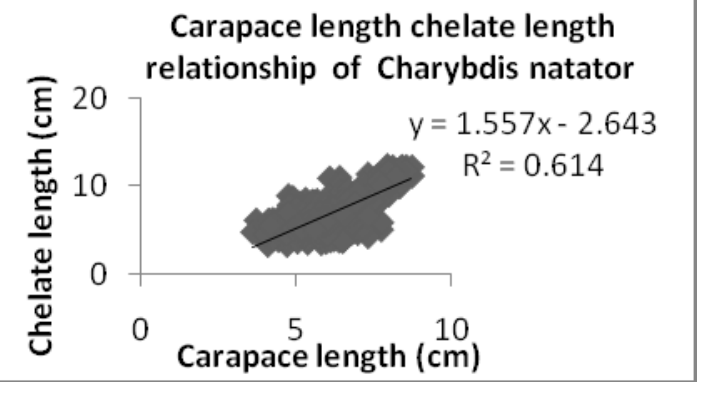 \\
\hline $\begin{array}{l}\text { Carapace length abdomen width } \\
\text { relationship of male Charybdis natator } \\
\\
\\
\text { Carapace length }(\mathrm{cm})\end{array}$ & 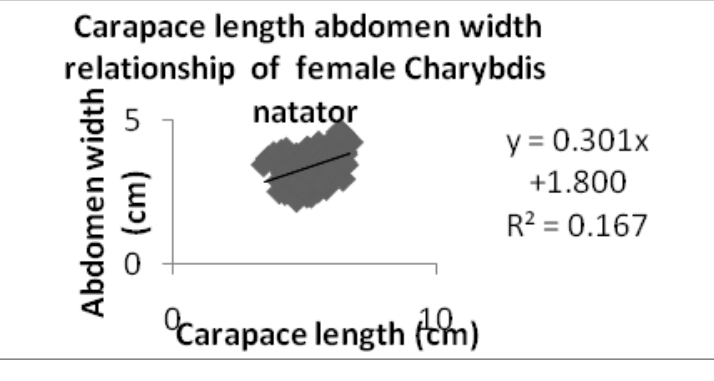 & 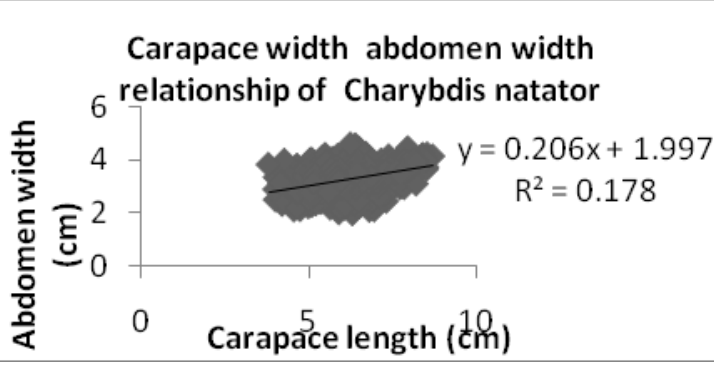 \\
\hline $\begin{array}{l}\text { Carapace width abdomen width } \\
\text { relationship of male Charybdis natator } \\
\text { Carapace width }(\mathrm{cm}) \\
\text { C }\end{array}$ & 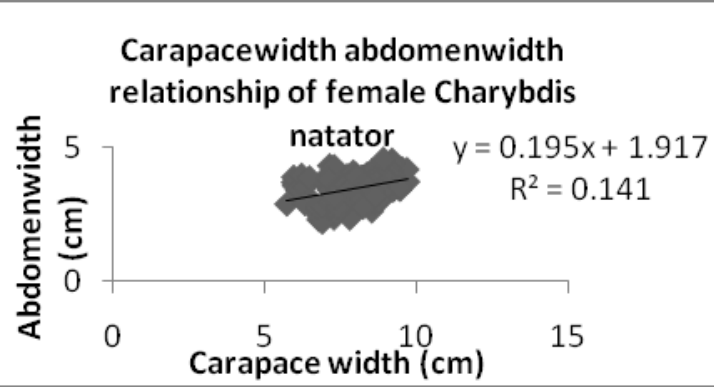 & 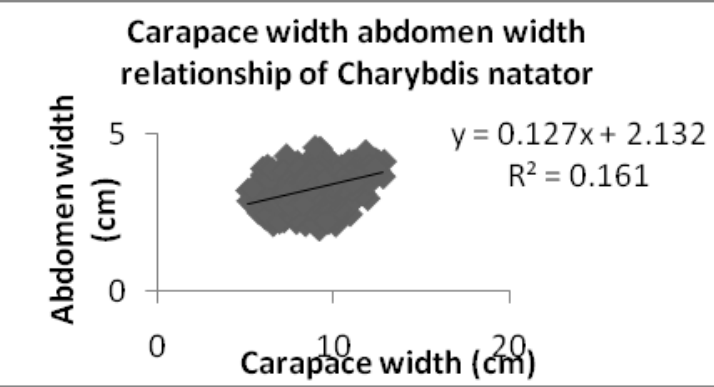 \\
\hline
\end{tabular}


Fig.5 Monthly size (Carapace length) frequency distribution for male and female C. natator in the study area

\begin{tabular}{|c|c|c|c|}
\hline 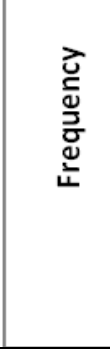 & 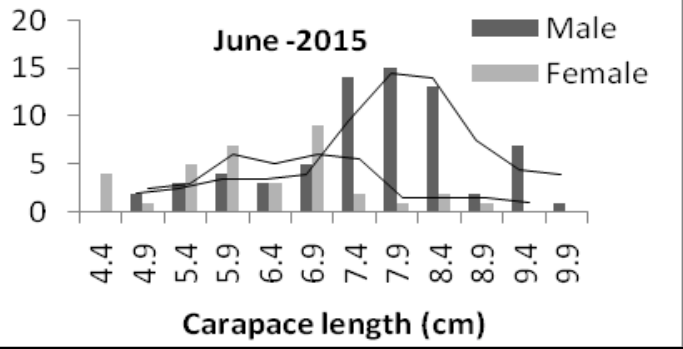 & 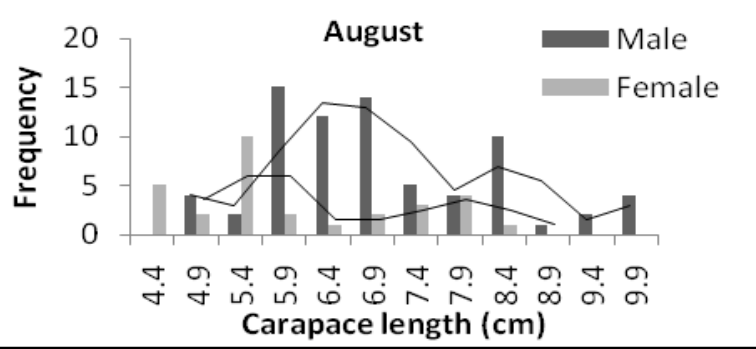 & 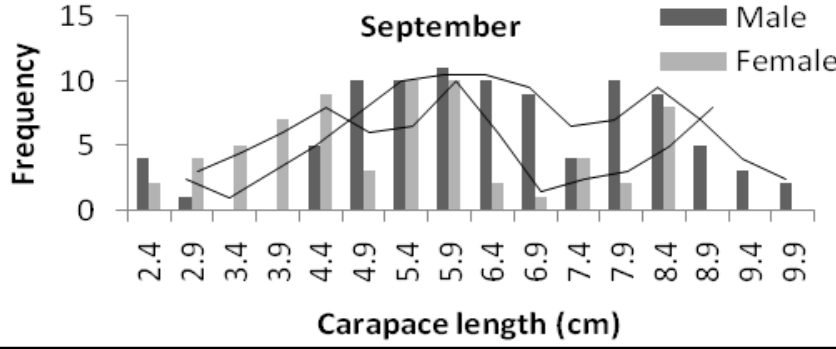 \\
\hline 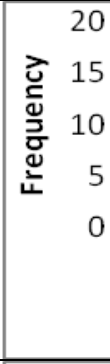 & 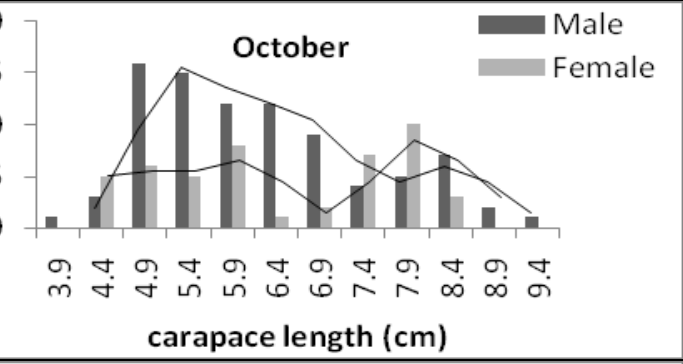 & 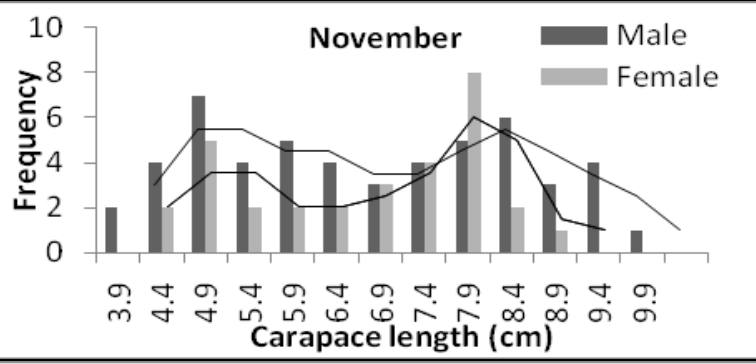 & 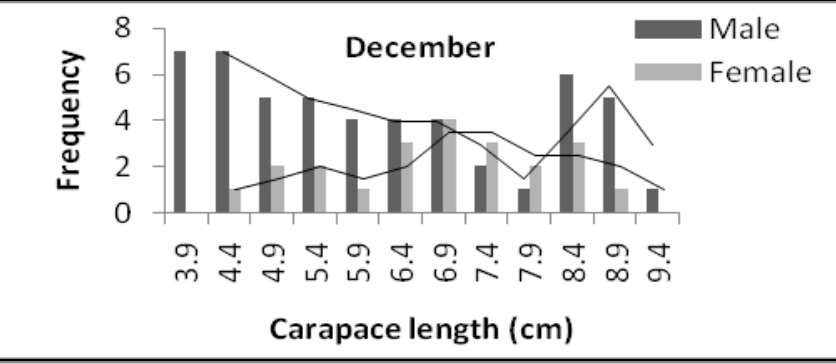 \\
\hline 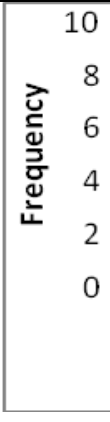 & 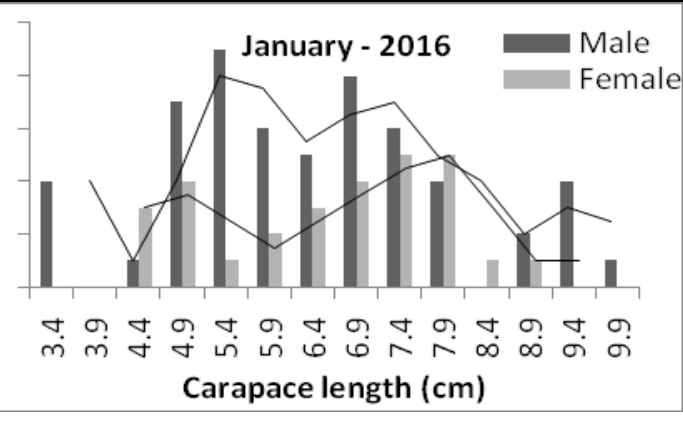 & 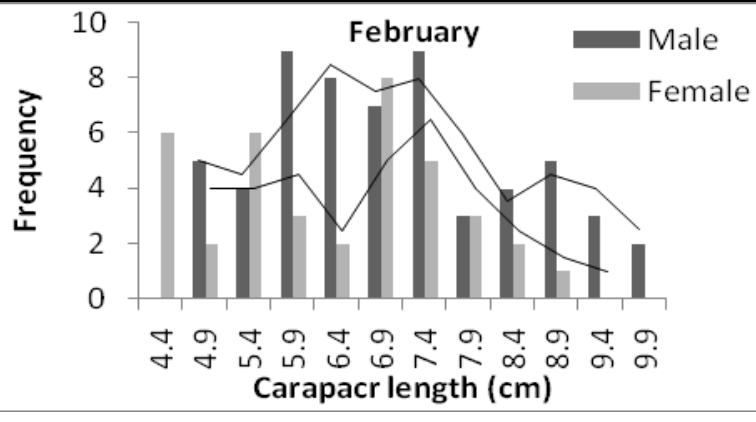 & 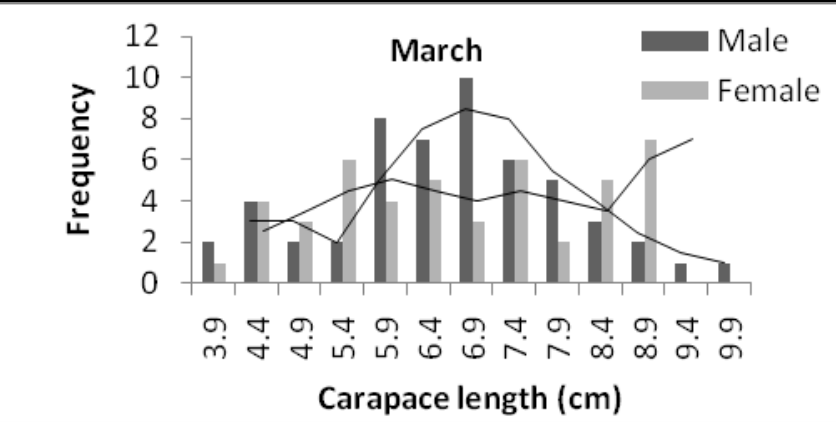 \\
\hline 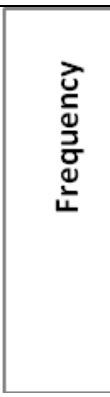 & 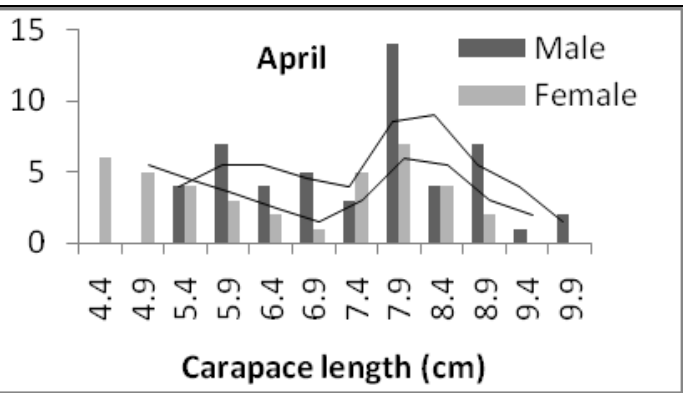 & 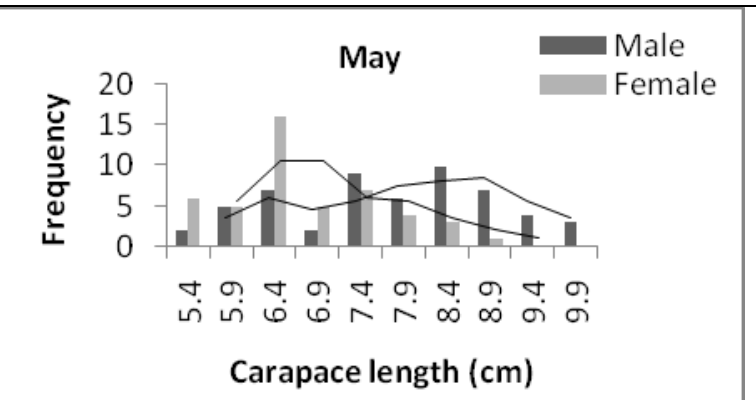 & 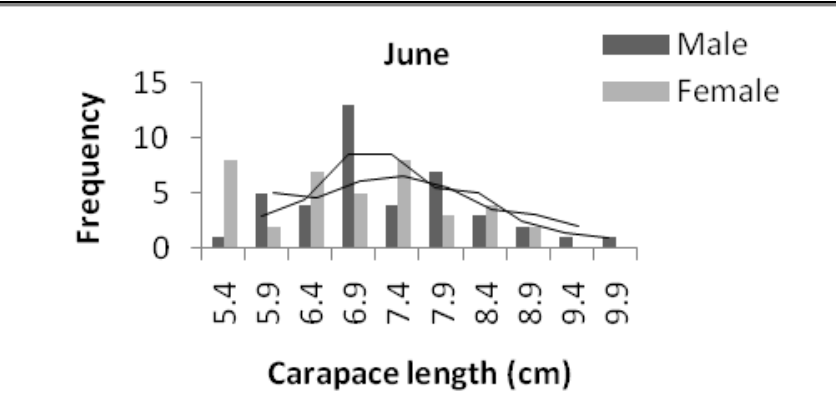 \\
\hline
\end{tabular}


Fig.6 Monthly size frequency (Carapace width) distribution for male and female C. natatorin the study area

\begin{tabular}{|c|c|c|}
\hline 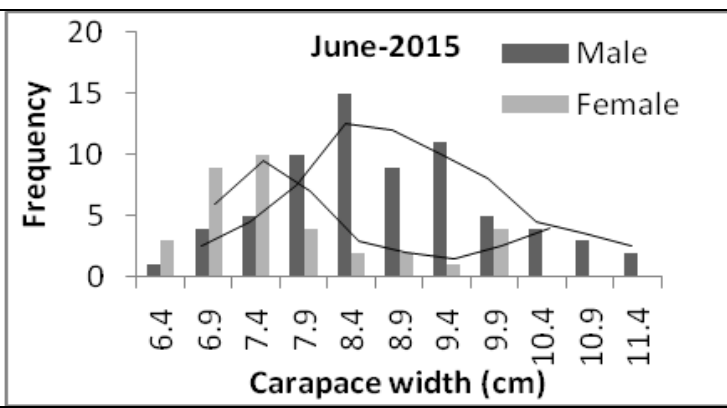 & Carapace width (cm) & 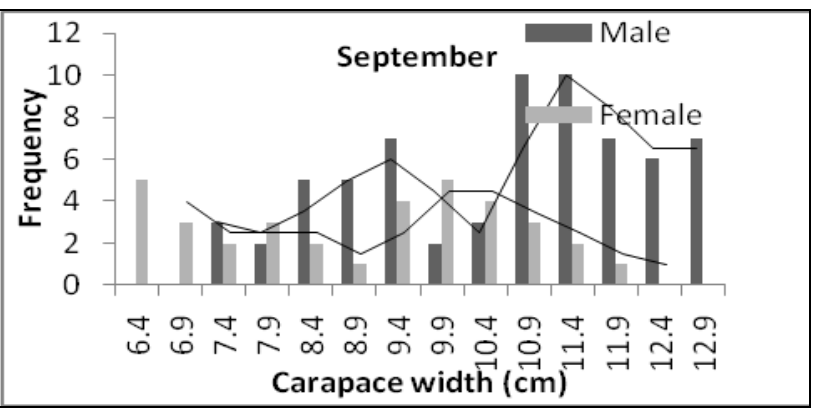 \\
\hline 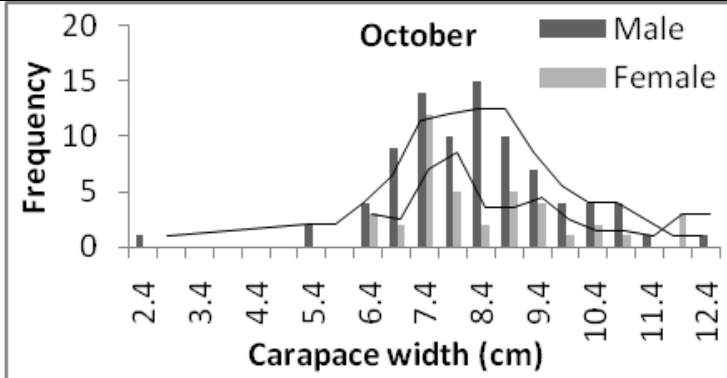 & 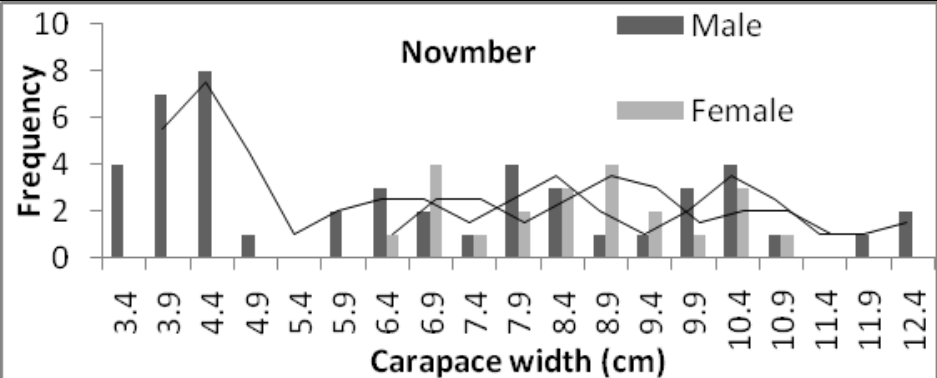 & 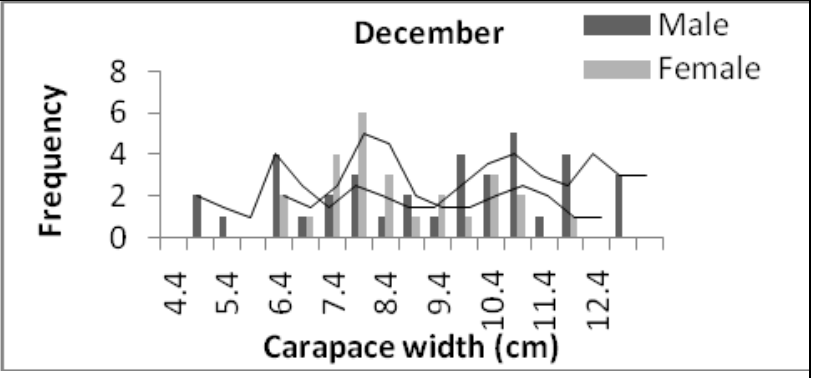 \\
\hline 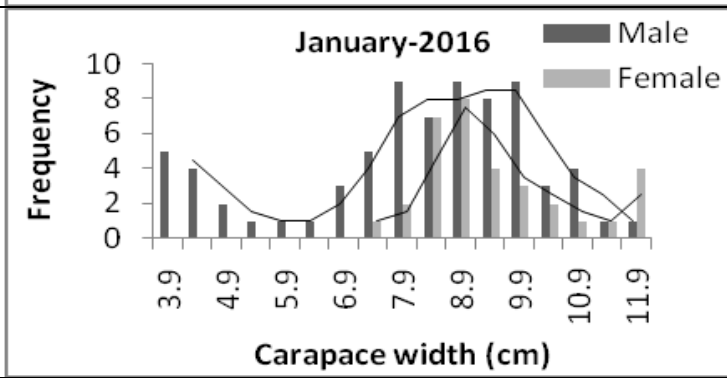 & 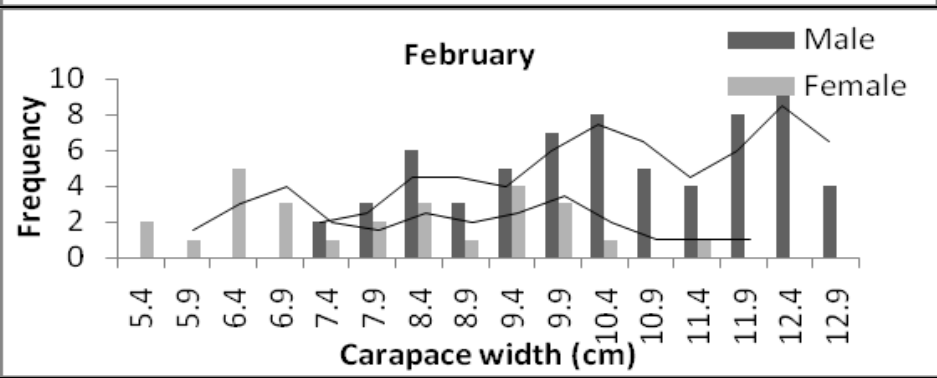 & 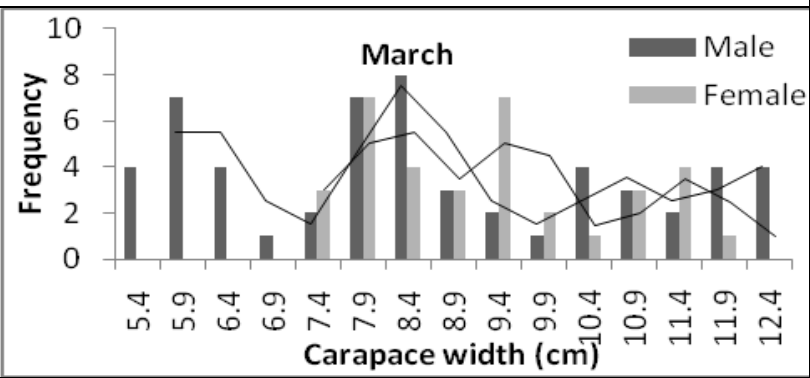 \\
\hline 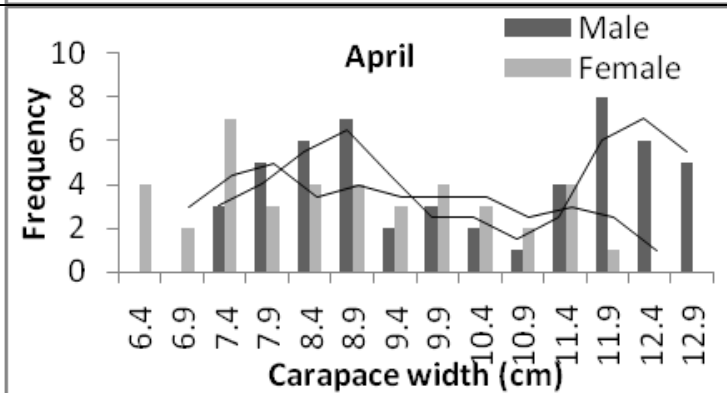 & 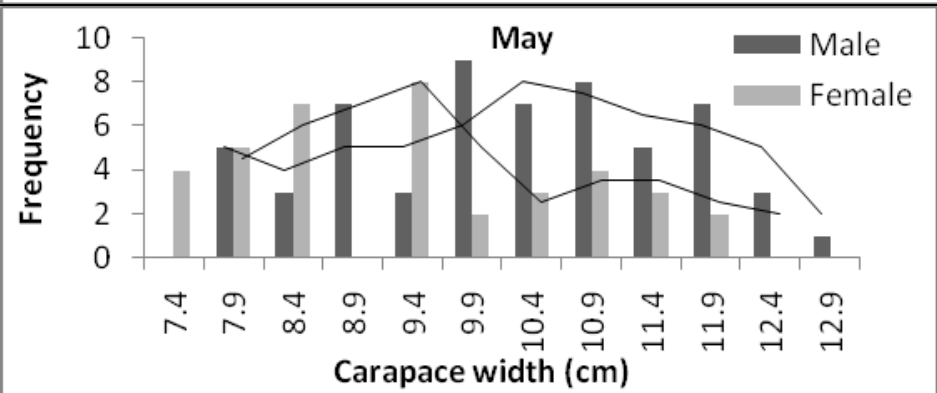 & Carapace width $(\mathrm{cm})$ \\
\hline
\end{tabular}


Fig.7 Monthly weight (Wt) frequency distribution for male and female C. natator in the study area

\begin{tabular}{|c|c|c|c|}
\hline & 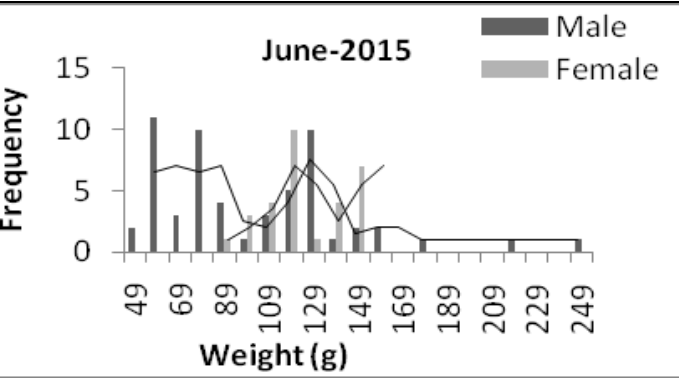 & 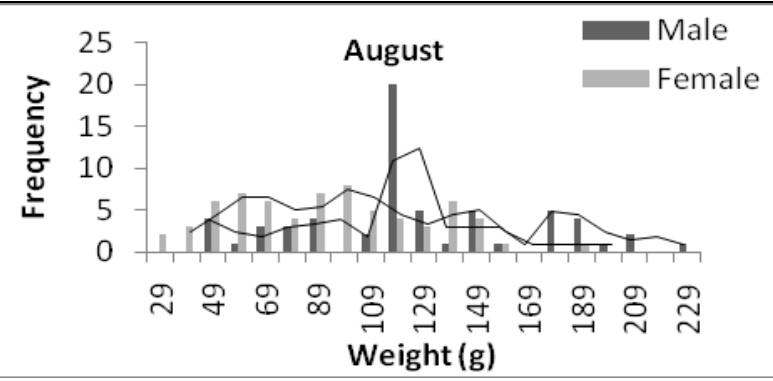 & 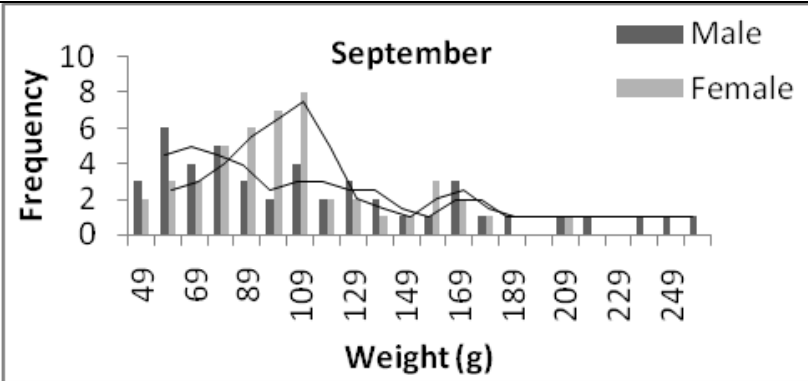 \\
\hline 文 & 10 October & 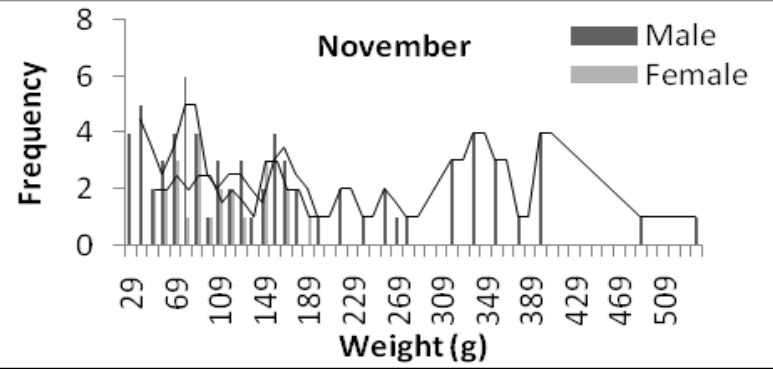 & December \\
\hline & 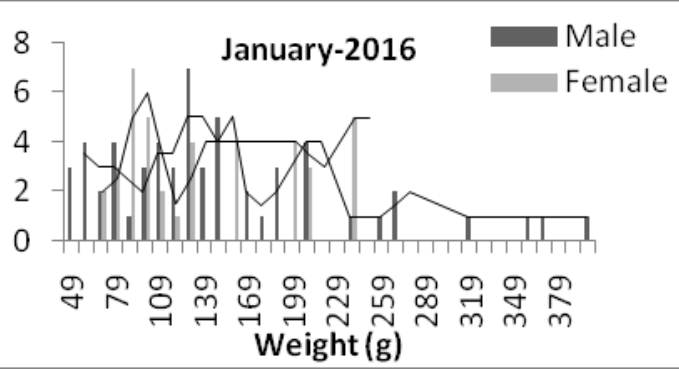 & 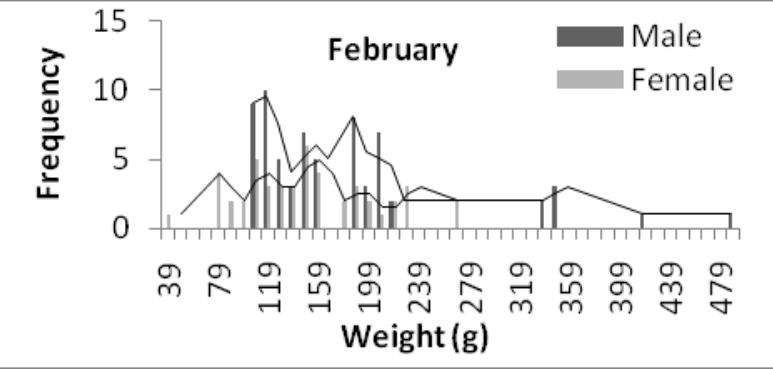 & 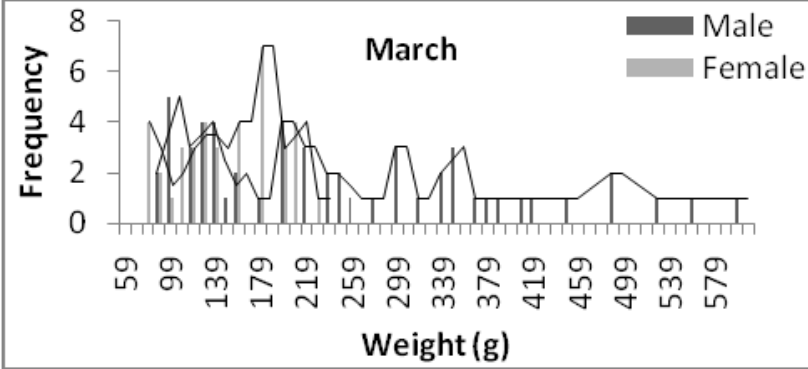 \\
\hline 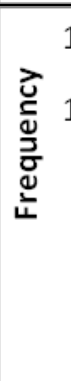 & April Male & $\begin{array}{c}15 \\
\text { May } \\
\text { Weight (g) }\end{array}$ & 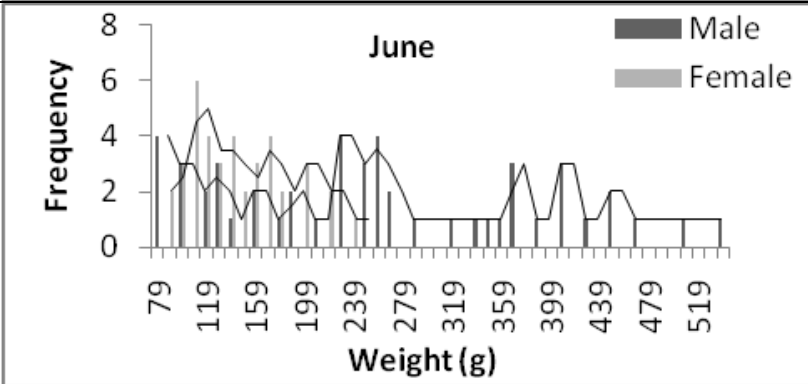 \\
\hline
\end{tabular}


The number of male population collected was found to be significantly higher than female population. Males $C$. natator reach a larger size than females as evidenced by the largest size class $12.8 \mathrm{~cm}$ Carapace width, consisting almost entirely of males. This size range is slightly lower than that reported for $C$. natator in Gulf of Suez, Red sea and in Moreton Bay, Australia (Sallam and GabAlla, 2010; Sumpton, 1990). The size range of male and female of C.affinis $4.2 \mathrm{~cm}$ and 3.6 $\mathrm{cm}$ was recorded in China (Chu, 1999). The size range of $C$. feriata was reported 4.6 to $17.0 \mathrm{~cm}$ in males and 2.6 to $15.5 \mathrm{~cm}$ in females from Karnataka coast (Dineshbabu, 2011). Since, the crab fishers venture into the deeper part of ocean for capturing, the size of crab caught was normally higher than the earlier records. The size range of $C$. natator in the trawl fishery was documented 4.7 and $14.85 \mathrm{~cm} \mathrm{CW}$ from Gulf of Suez (Sallam and Gab- Alla, 2010). The size structure is often variable within a species and may be subjected to environmental influences (Kuhlmann and Walker, 1999). This might be due to the spatial variation or might be due to the gear employed. There are seasonal effects on crab abundance due to different climate conditions such as rainfall and temperature fluctuations.

In the present study shows that Males population was more abundant than female population, the same report was observed in Moreton Bay, Australia (Sumpton, 1990), which was attributed to reproductionassociated migration during their productive season. Sex ratio deviations in crab populations usually involve sexual differences in longevity (survival rate), migration, growth rate, and even sex reversal (Thomas, 1984). Hence it is suggested that the variation in sex ratio mainly depends on migration of crab for feeding, breeding, types of gear and craft used in that season. The value of exponent ' $b$ ' was found, the $C$. natator males displayed the positive allometric (b>3) growth in $\mathrm{CW}-\mathrm{BW}$ relationship and in CL-BW and Chelate length $-\mathrm{BW}$ relationship showed is negative allometric growth (Table 2). But in female CL-BW and CW-BW showed almost isometric growth $(b=3)$. Further the ' $b$ ' values indicated that the males are heavier than females at a given width and length against weight in $C$. natator, which is in accordance with the finding from Mangalore, Kakinada and Karnataka coast in C. feriata (Dineshbabu, 2011; Laithadevi, 1985; Rameshbabu et al., 2002). The slight differences in exponential values may possibly due to differential diet presumably resulting from size difference, change in cheliped strength, foraging behavior and metabolic rate of animal. From the available literature information on the length - weight relationship of $C$. natator is scanty. In the present study, the males of $C$. natator being heavier than females is also in conformity with the earlier observations in $P$. pelagicus (Potter et al., 1983; Thomas, 1984) and $P$. Sanguinolentus (Herbst, 1783), from Cochin (Thomas, 1984) and Mangalore (Sukumaran et al., 1986). In $P$. sanguinolentus, $P$. pelagicus and Scylla serrate (Forskål, 1775) from Karwar (Prasad et al., 1989) and in $P$. Pelagicus and $P$. sanguinolentus from Mangalore (Sukumaran and Neelakantan, 1997). Crabs generally, males reaching a larger size since females expend greater resources on reproduction, at the expense of growth (Hartnoll, 1982).

From this study, concluded that the males of C. natator heavier than females. Growth rate differences between males and females result mainly from the greater reproductive output of females when crabs became sexually mature, growth often decreases because the significant amount of energy used for the reproduction but males were spend their energy only for somatic growth. 


\section{Acknowledgement}

The authors thank Dr. G. Sugumar, Dean, Fisheries College and Research Institute, Thoothukudi, India for his valuable guidance, persistent support, motivation and extending the facilities to undertake this work.

\section{References}

Chu, K. H.1999. Morphometric analysis and reproductive biology of the crab Charybdis affinis (Decapoda, Brachyura, Portunidae) from the Zhujiang Estuary, China. Crustaceana. 72:647-657.

Dineshbabu, A.P.2 011. Biology and exploitation of the crucifix crab, Charybdis feriata (Linnaeus, 1758) (Brachyura: Portunidae) from Karnataka coast, India. Indian J. Fish. 58(1):25-29.

Hartnoll, R.G.H.1982. Growth In: D. E. Bliss and L. G. Abele (eds.), The Biology of Crustacea. Embryology, Morphology and Genetics, Academic Press, New York. 2: 119-116.

Kathirvel, M. 2008. Biodiversity in edible crabs of India. In: Johnmiltan, C., (Eds), Training manual on GIS and Marine Biodiversity, Loyala College Publication.

Kuhlmann, M.L. and Walker, R.E.1999. Geographic variation in size structure and size at maturity in the crab Pilumnussayi (Crustacea: Decapoda: Xanthidae) in the northern Gulf of Mexico. Bull. Mar. Sci.64 (3): 535-541.

Laithadevi, S. 1985. The fishery and biology of crabs of Kakinada region. Indian. J. Fish. 32(1): $18-31$.

Potter, I.C., Chrystal, P.J., Loneragan, N.R. 1983.
The biology of the blue manna crab Portunu spelagicus in an Australian estuary. Mar. Biol., Berlin. 78:75-85.

Prasad, P.N, Reeby, J. Kusuma, N. Neelakantan, B. 1989.Width-weight and length weight relationship in three portunid crab species. Uttar Pradesh Journ. Zool. 9(1): 116-120.

Rameshbabu, K.V., Benakappa, S., Chandra Mohan, K. 2002. Length - weight relationship in Charybdis (Charybdis) feriatus(Linnaeus) from Mangalore region. IndianHydrobiol.5 (1): 9-14.

Sallam, W.S., Gab- Alla, A.A.2010. Some biological aspects of the portunid crab Charybdisnatatorfrom the Gulf of Suez, Red sea, Egypt. J. Aquat. Biol. \& Fish. 14: 39-51.

Sukumaran, K.K. and Neelakantan B (1997). Length-weight relationship in two marine portunid crabs, Portunus (Portunus) sanguinolentus (Herbst) and Portunus (Portunus) pelagicus (Linnaeus) from the Karnataka coast. Indian Journ. Mar. Sci. 26(1): 39-42.

Sukumaran, K.K., Telangand, K.Y., Thippeswamy, D. 1986. On the fishery and biology of the crab Portunus sanguinolentus (Herbst) along the south Kanara coast. Indian J. Fish, 33(2): 188-200.

Sumpton, W. 1990. Biology of the rock crab Charybdis natator (Herbst) (Brachyura: Portunidae). Bulletin of Marine Science. 46(2): 425-431.

Thomas, M. 1984. Studies on portunid crabs (Crustacea: Decapoda: Brachyura). (Ph.D. Thesis), Department of Marine Sciences, University of Cochin, Cochin. Pp. 1-155.

Wenner, A.M. 1972. Sex ratio as a function of size in marine Crustacea. Amer. Natur. 106: $321-350$.

\section{How to cite this article:}

Vidhya, V., P. Jawahar and Karuppasamy, K. 2018. Morphometrics and Length-weight Relationship of Charybdis natator from Gulf of Mannar, India. Int.J.Curr.Microbiol.App.Sci. 7(12): 797-808. doi: https://doi.org/10.20546/ijcmas.2018.712.100 